\title{
Pyrosequencing for rapid detection of Tuberculosis resistance in clinical isolates and Sputum samples from re-treatment Pulmonary Tuberculosis patients
}

Ruijuan Zheng ${ }^{1}$, Changtai Zhu ${ }^{3 *}$, Qi Guo ${ }^{1}$, Lianhua Qin ${ }^{1}$, Jie Wang ${ }^{1}$, Junmei Lu${ }^{1}$, Haiyan Cui ${ }^{1}$, Zhenling Cui ${ }^{1}$, Baoxue $\mathrm{Ge}^{1}$, Jinming $\mathrm{Liu}^{2^{*}}$ and Zhongyi $\mathrm{Hu}^{1 *}$

\begin{abstract}
Background: Multidrug-resistant tuberculosis (MDR-TB) is a major public health problem. Early diagnosis of MDR-TB patients is essential for minimizing the risk of Mycobacterium tuberculosis (MTB) transmission. The conventional drug susceptibility testing (DST) methods for detection of drug-resistant M.tuberculosis are laborious and cannot provide the rapid detection for clinical practice.

Methods: The aim of this study was to develop a pyrosequencing approach for the simultaneous detection of resistance to rifampin (RIF), isoniazid (INH), ethambutol (EMB), streptomycin (SM), ofloxacin (OFL) and amikacin (AMK) in M. tuberculosis clinical isolates and sputum samples from re-treatment pulmonary tuberculosis (PTB) patients. We identified the optimum conditions for detection mutation of $r p o B, k a t G$, rpsl, embB, gyrA and rrs gene by pyrosequencing. Then this approach was applied to detect 205 clinical isolates and 24 sputum samples of M. tuberculosis from re-treatment PTB patients.

Results: The mutations of $r p \circ B$ and gyrA gene were detected by pyrosequencig with the SQA mode, and the mutations of $k a t G, r p s l, e m b B$, gyrA and rrs gene were detected by pyrosequencing with SNP mode. Compared with the Bactec MGIT 960 mycobacterial detection system, the accuracy of pyrosequencing for the detection of RIF, INH, EMB, SM, AMK and OFL resistance in clinical isolates was 95.0\%, 79.2\%, 70.3\%, 84.5\%, 96.5\% and 91.1\%, respectively. In sputum samples the accuracy was $83.3 \%, 83.3 \%, 60.9 \%, 83.3 \%, 87.5 \%$ and $91.7 \%$, respectively.

Conclusions: The newly established pyrosequencing assay is a rapid and high-throughput method for the detection of resistance to RIF, INH, SM, EMB, OFL and AMK in M.tuberculosis. Pyrosequencing can be used as a practical molecular diagnostic tool for screening and predicting the resistance of re-treatment pulmonary tuberculosis patients.
\end{abstract}

\footnotetext{
* Correspondence: zct101@163.com; jinmingliu_sh@hotmail.com; shtblab@163.com

${ }^{3}$ Department of Laboratory Medicine, Shanghai Jiao Tong University

Affiliated Sixth People's Hospital, No. 600 Yishan Rd, Shanghai 200233, China

${ }^{2}$ Department of Respiratory Medicine, Shanghai Pulmonary Hospital, Tongji

University School of Medicine, No. 507 Zhengmin Rd, Shanghai 200433,

People's Republic of China

'Shanghai Key Laboratory of Tuberculosis, Shanghai Pulmonary Hospital,

Tongji University School of Medicine, No. 507 Zhengmin Rd, Shanghai

200433, People's Republic of China
}

\section{Biomed Central}

(c) 2014 Zheng et al.; licensee BioMed Central Ltd. This is an Open Access article distributed under the terms of the Creative Commons Attribution License (http://creativecommons.org/licenses/by/2.0), which permits unrestricted use, distribution, and reproduction in any medium, provided the original work is properly credited. 


\section{Background}

The emergence and spread of MDR-TB and extensively drug-resistant tuberculosis (XDR-TB) posed a severe impediment for the prevention and control of tuberculosis (TB) transmission [1-3]. According to the World Health Organization (WHO) [4], there were about 650,000 cases of MDR-TB present in the world in 2010, and was estimated that about $9 \%$ of these cases of XDR-TB. Annually, about 440,000 were infected with MDR-TB and 150,000 died of MDR-TB. Due to the severity of MDR$\mathrm{TB}$, the WHO convened a international meeting focused on MDR-TB in April 2009 in Beijing, China, urging member states to take detailed and effective action in diagnosing and treating M/XDR-TB [4]. Another survey of WHO in 2010 showed that the estimated MDR-TB among the notified re-treatment cases $(\mathrm{n}=7,795)$ was 2,200 (28\%) [5]. So the Global Plan to STOP TB (20062015) proposed that by 2015 all countries should carry out DST for all re-treatment tuberculosis patients [6]. In order to control the MDR-TB,it was important for retreatment PTB patients to develop a rapid, reliable and high-throughput drug susceptibility testing to obtain firstand second-line anti-tuberculosis drugs susceptibility result simultaneously, as it was essential to decrease patient morbidity and mortality as well as treatment-associated costs.

At present, the conventional drug susceptibility testing methods for M.tuberculosis were the bacteriological methods performed by culture in liquid or on solid media with highly sensitive and specific to most anti-TB drugs. However, these methods were laborious, time-consuming and could not provide rapid detection for clinical practice. Consequently, the rapid molecular diagnostic methods which performed within 1 or 2 days would be helpful for shortening the detection time.

Spontaneous chromosomal mutations were the genetic basis for drug resistance in M. tuberculosis [7,8]. At present, RIF resistance was almost entirely associated with the mutation of an 81-bp region of the rpoB gene, the RIF resistance determining region (RRDR) [9-11]. The resistance to INH, EMB, SM, OFL and AMK was primarily found in mutations in the katG, embB, rpsl, gyrA and rrs genes, respectively [8,12-16]. All these resistance-associated mutations were predominantly found in a short region or a position in $M$. tuberculosis genome and could be considered as the beacons of molecular drug susceptibility testing. Currently, the WHO endorsed some molecular methods to detect individual anti-TB drugs susceptibility by detecting gene mutations associated with drug resistance, such as Xpert MTB/RIF [17] and GenoType MTBDR [18] methods.

Pyrosequencing was a DNA sequencing technique that was based on the detection of the pyrophosphate released during DNA synthesis [19-21], and was well suitable for large-scale screening for a short length DNA fragment. At present, pyrosequencing had become a novel approach for the detection of TB infection and tuberculosis resistance [22-25]. Compared to GenoType MTBDR method, pyrosequencing was more accurate and easier to handle. Compared to Xpert MTB/RIF method, pyrosequencing could detect more drugs resistance. In this study, our aim was to establish a rapid molecular method for the detection of tuberculosis resistance by pyrosequencing technology and to evaluate its clinical value in re-treatment pulmonary tuberculosis patients.

\section{Methods}

\section{Ethics considerations}

The Shanghai Pulmonary Hospital Affiliated to Tongji University School of Medicine Ethics Committee approved the research protocols (permit number: 2010034). The informed consent was obtained from each patient who was treated in accordance with the Helsinki Declaration on the participation of human subjects in medical research.

\section{Source of clinical isolates and sputum samples}

A total of 205 clinical M.tuberculosis isolates and $24 \mathrm{spu}-$ tum samples were obtained from PTB patients in Shanghai Pulmonary Hospital from January 2010 to March 2011. All the sputum specimens were smear-positive and were classified according to an acid-fast bacillus (AFB) staining scale as $1+(1$ case $), 2+$ ( 3 cases $), 3+(12$ cases $)$ and $4+$ ( 8 cases). All of the samples were identified as $M$. tuberculosis by Bactec MGIT 960 culture, Ziehl-Neelsen staining and standard biochemical identification testing [26] and all of the samples were collected from retreatment PTB patients. The re-treatment PTB definition was a patient who failed the standard initial tuberculosis treatment regimen, who relapsed after initial treatment with a standard or non-standard tuberculosis regimen. In addition, 10 clinical isolates, including 3 isolates susceptibility and 2 isolates resistant to RIF, INH, EMB, SM, AMK and OFL and the other 5 isolates resistant to four or five drugs, were collected from Shanghai Pulmonary Hospital. These isolates were sequenced on an ABI 3730xl DNA Analyzer by the Sangon Engineering Company (Shanghai, China) to obtain the sequence of rpoB, katG, embB, rrs, gyrA and rpsl genes. M.tuberculois standard strain (H37Rv, ATCC25618) was purchased from the National Culture Collection.

\section{Specimen processing and genomic DNA extraction}

For M.tuberculosis isolates, genomic DNA extraction was performed as described previously [22]. For sputum samples, prior to DNA extraction, each sputum sample was decontaminated with an equal volume of $2 \% \mathrm{NaOH}$ and $0.5 \%$ NALC, incubated at room temperature for $20 \mathrm{~min}$, 
neutralized with $67 \mathrm{mM}$ phosphate buffer ( $\mathrm{pH}$ 6.8) and then centrifuged at $3,300 \times g$ for $20 \mathrm{~min}$ at $4^{\circ} \mathrm{C}$. The processed sediment was washed once using a sterile $0.9 \% \mathrm{NaCl}$ solution and re-suspended in $1.0 \mathrm{ml}$ sterile $0.9 \% \mathrm{NaCl}$ solution. Two separate $500 \mu \mathrm{l}$ aliquots were prepared in $1.5 \mathrm{ml}$ tubes for the DNA extraction and Bactec MGIT 960 culture. The $500 \mu \mathrm{l}$ aliquots for the DNA extraction were inactivated and lysed for $30 \mathrm{~min}$ at $85^{\circ} \mathrm{C}$ and DNA extraction was performed as described above for the extraction of clinical isolates previously. The concentration of the genomic DNA was measured by the Biophotometer (Eppendorf).

\section{Design of primers and PCR amplification}

Regions of the rpoB, $k a t G, e m b B, r r s, g y r A$ and rpsl genes were amplified by conventional PCR. Amplification and sequencing primers for pyrosequencing were designed with PSQ assay design software (Biotage, Inc., Charlottesville, VA). Primers and amplicon sizes were presented in Table 1. Amplification reaction was performed in a final volume of $50 \mu \mathrm{l}$ consisting of $0.5 \mu \mathrm{l} 10 \times \mathrm{PCR}$ buffer, $0.2 \mathrm{mM}$ deoxynucleotide triphosphates (Takara), 1U Taq DNA polymerase (Takara), $200 \mathrm{nM}$ of each primer, and $10 \mathrm{ng}$ of DNA. Thermo-cycling conditions were as follows: $95^{\circ} \mathrm{C}$ for $3 \mathrm{~min}$ followed by 50 cycles of $30 \mathrm{~s}$ at $95^{\circ} \mathrm{C}, 30 \mathrm{~s}$ at respective annealing temperature, $30 \mathrm{~s}$ at $72^{\circ} \mathrm{C}$ and final elongation at $72^{\circ} \mathrm{C}$ for $10 \mathrm{~min}$.

\section{Protocols of pyrosequencing}

Pyrosequencing was performed using PyroMark 96MA instrument (Qiagen, formerly Biotage AB, Inc.). PSQ 96MA system had two modes to detect gene mutation. One was dedicated sequence analysis (SQA) Software which could give true sequence information about 50 bases. The other was single-nucleotide polymorphism (SNP) Software which could support fast genotyping results.

To determine the optimal mutation detection modes for rpoB, katG, rpsl, embB, gyrA and rrs genes, 10 collected M.tuberculosis clinical isolates with known sequence by Sanger Sequencing were detected gene mutations by pyrosequencing with both SQA mode and SNP mode. Then the results from pyrosequencing were compared with the gold standard "Sanger sequencing" results by the Identifire software. The pyrosequencing results were considered valid if the pyrosequencing results were consistent with Sanger Sequencing results. The detection mode and the nucleotide dispensation order of pyrosequencing were considered optimum if pyrosequencing results were valid and the assay could consume less detection time and reagent. The conditions were presented in Table 2.

The gene mutations of 205 M.tuberculosis clinical isolates and 24 sputum samples were detected by pyrosequencing under the optimal conditions as considered above.

Table 1 Primers and thermo-cycling conditions of the pyrosequencing assays

\begin{tabular}{|c|c|c|c|c|c|c|}
\hline Drug & Gene & Primer & Sequences $\left(5^{\prime}-3^{\prime}\right)$ & Annealing temperature $\left({ }^{\circ} \mathrm{C}\right)$ & Size (bp) & Target loci \\
\hline \multirow[t]{4}{*}{ RIF } & $r p o B$ & Forward & GTCCGGGAGCGGATGACCACCC & 65 & 204 & RRDR \\
\hline & & Reverse* & GCTCACGTGACAGACCGCCG & & & \\
\hline & & Sequencing 1 & GCGATCAAGGAGTTC & & & \\
\hline & & Sequencing 2 & TCATGGACCAGAACAA & & & \\
\hline \multirow[t]{3}{*}{$\mathrm{INH}$} & katG & Forward & AGATGGGCTTGGGCTGGA & 61 & 133 & 315 \\
\hline & & Reverse $^{*}$ & TAGCCGTACAGGATCTCGAGGA & & & \\
\hline & & Sequencing & CCGGTAAGGACGCGA & & & \\
\hline \multirow[t]{4}{*}{ SM } & rpsl & Forward* & CAAGGGTCGTCGGGACAAGA & 61 & 299 & \\
\hline & & Reverse & TCTTGACACCCTGCGTATCC & & & \\
\hline & & Sequencing 1 & CGCCGAGTTCGGCTT & & & 43 \\
\hline & & Sequencing 2 & CACACCAGGCAGGTC & & & 88 \\
\hline \multirow[t]{3}{*}{ EMB } & $e m b B$ & Forward & ACGACGGCTACATCCTGG & 61 & 110 & 306 \\
\hline & & Reverse* & GTTGTAATACCAGCCGAAGGGA & & & \\
\hline & & Sequencing & CGACGGCTACATCCTG & & & \\
\hline \multirow[t]{3}{*}{ OFL } & gyrA & Forward & TTCGATTCCGGCTTCCGCCC & 61 & 192 & QRDR \\
\hline & & Reverse $^{*}$ & TGGGTCATTGCCTGGCGAGC & & & \\
\hline & & Sequencing & TACCACCCGCACGGC & & & \\
\hline \multirow[t]{3}{*}{ AMK } & rrs & Forward & TCCTTAAAAGCCGGTCTCAGTTC & 61 & 239 & 1401 \\
\hline & & Reverse $^{*}$ & TCCGGTACGGCTACCTTGTTA & & & \\
\hline & & Sequencing & CTTGTACACACCGCC & & & \\
\hline
\end{tabular}

*: The primer was labeled at the 5-end with biotin. 
Table 2 Optimum conditions for detection mutation of rpoB, katG, gyrA, rrs, embB and rpsl genes by pyrosequencing

\begin{tabular}{lll}
\hline Loci & Detection mode & Nucleotide dispensation order \\
\hline rpoB & SQA mode & RRDR mutation: 16(AGCT) \\
katG & SNP mode & 315 mutation: GTCACAGTCTG \\
$r$ rsl & SNP mode & 43 mutation: CGATACGAGT88 mutation: CGATGCACGC \\
embB & SNP mode & 306 mutation:TGCAGTGACGCGCAGT \\
gyrA & SQA mode & QRDR mutation: 12(GACT) \\
rrs & SNP mode & 1401 mutation: TCGTCAGTCAGTCAT \\
\hline
\end{tabular}

In brief, pyrosequencing method included preparation of the template and sequencing reaction. Firstly the PCR amplification product immobilized on the streptavidincoated sepharose beads (GE Healthcare, Uppsala, Sweden) was converted into single-stranded DNA template and purified with a vacuum preparation tool. Then a sequencing primer was subsequently annealed to the template. Pyrosequencing was performed in an automated PyroMark 96MA instrument according to the manufacturer's instructions. For the SQA mode detection, a PyroMark Gold Q96 SQA reagents (Qiagen, 972812) and cyclic dispensation of the nucleotide was used. The resultant sequences were compared with a database containing sequences of known mutations by mean of the Identifire software. The mutation types and loci were determined using alignment with the sequence results of M.tuberculosis H37Rv (ATCC25618, and GenBank accession no. NC_000962) [27]. For the SNP mode, the genotyping results were directly obtained by using the PyroMark Gold Q96 reagents (Qiagen, 972804). During pyrosequencing testing, amplified H37Rv genomic DNA was employed as a control. Some new nucleotide sequences were submitted to the Genbank (Accession numbers: KJ659894, KJ659895, KJ659896, KJ659897, KJ659898, KJ659899, KJ659900, KJ659901, KJ659902).

\section{DST of M.tuberculosis by the Bactec MGIT 960 system}

DST was performed using the Bactec MGIT 960 mycobacterial detection system. Drug concentrations used in the MGIT 960 system were: RIF: $1.0 \mu \mathrm{g} / \mathrm{ml}$, INH: $0.1 \mu \mathrm{g} /$ ml, SM: $1.0 \mu \mathrm{g} / \mathrm{ml}$, EMB: $5.0 \mu \mathrm{g} / \mathrm{ml}$, OFL: $2.0 \mu \mathrm{g} / \mathrm{ml}$ and AMK: $1.0 \mu \mathrm{g} / \mathrm{ml}[28]$.

\section{Statistical analysis}

Data analysis was carried out using Stata version 9 (Statacorp, Texas, USA). The sensitivity, specificity and accuracy were calculated for pyrosequencing results versus Bactec MGIT 960 system results. The Bactec MGIT 960 system results were considered as the gold standard of DST for comparison with the results obtained from pyrosequencing. The agreement between the pyrosequencing results and Bactec MGIT 960 results was analyzed using Kappa value.

\section{Results}

\section{DST using Bactec MGIT 960 system}

DST of RIF, INH, SM, EMB, OFL and AMK was detected by Bactec MGIT 960 system. Of the 229 retreatment PTB patients samples, $89.5 \%$ cases were identified resistant to at least one of the tested drugs, above $50 \%$ cases were resistant to four or five tested drugs and $6.6 \%$ cases were resistant to only one drug.

\section{Pyrosequencing results for the detection of gene mutations}

All of the 205 clinical isolates and 24 sputum samples, pyrosequencing identified 10 kinds of codon involving in 39 types of mutations in RRDP of the $r p o B$ gene, and $60.4 \%(110 / 182)$ and $20.3 \%(37 / 182)$ of the RIF-resistant clinical samples had a mutation at the codon 531 and 526, respectively, in Table 3. The 74.2\% (141/190) of the INH-resistant clinical samples had a mutation at codon 315 in the katG gene. No mutation in katG S315 was found in INH-susceptible clinical samples. The $65.4 \%$ $(100 / 153)$ and $11.8 \%(18 / 153)$ of the SM-resistant clinical samples had a mutation at the codon 43 and 88 , respectively, in the rpsl gene. The $55.5 \%(76 / 137)$ of the EMB-resistant clinical samples had a mutation at codon 306 in the $e m b B$ gene. There were four kinds of codons including 12 types of mutations in the regions of the quinolone resistance-determining regions (QRDR) of the gyrA gene, and 62\% (88/142) of the OFL-resistant clinical samples had a mutation at codon 94. The 77.3\% (34/ 44) of the AMK-resistant clinical samples showed a mutation in position 1401 in the rrs gene, and no mutation in this position was found in AMK-susceptible clinical samples. Mutations of the katG, embB, rrs, gyrA and rpsl genes were identified by pyrosequencing shown in Table 4 . The detailed information of sequences were provided in the Additional file 1

\section{The performance of pyrosequencing for the detection of TB resistance}

Compared with Bactec MGIT 960 method, pyrosequencing showed higher sensitivity and specificity in RIF, OFL, AMK and SM than in INH and EMB. The detection of EMB resistance showed the lowest sensitivity among six drugs not only in clinical isolates $(58.7 \%)$ but also in 
Table 3 Mutations of the rpoB gene identified by pyrosequencing in clinical isolates and sputum samples

\begin{tabular}{|c|c|c|c|}
\hline \multirow{2}{*}{$\begin{array}{l}\text { Amino acid } \\
\text { change(s) }\end{array}$} & \multirow{2}{*}{$\begin{array}{l}\text { Codon } \\
\text { change(s) }\end{array}$} & \multicolumn{2}{|c|}{ BACTEC MGIT 960 tests } \\
\hline & & $\mathrm{R}$ & $\mathrm{s}$ \\
\hline L511P & CTG/CCG & 1 & 1 \\
\hline Q513H & CAA/CAC & 1 & \\
\hline D516N & GAC/AAC & 1 & \\
\hline D516A & GAC/GCC & 1 & \\
\hline D516G & GAC/GGC & 3 & \\
\hline D516V & GAC/GTC & 5 & \\
\hline D516Y & GAC/TAC & 1 & 1 \\
\hline D516F & GAC/TTC & 1 & \\
\hline N518S & AAC/AGC & 1 & \\
\hline $\mathrm{H} 526 \mathrm{~N}$ & CAC/AAC & 4 & \\
\hline H526Q & CAC/CAG & 1 & \\
\hline H526R & CAC/CGC & 2 & \\
\hline H526D & CAC/GAC & 9 & \\
\hline H526Y & CAC/TAC & 6 & \\
\hline H526C & $\mathrm{CAC} / \mathrm{TGC}$ & 5 & \\
\hline H526F & $\mathrm{CAC} / \mathrm{TTC}$ & 1 & \\
\hline S531T & TCG/ACG & 2 & \\
\hline S531Y & TCG/TAT & 2 & \\
\hline S531W & TCG/TGG & 5 & \\
\hline S531L & $\mathrm{TCG} / \mathrm{TTG}$ & 92 & \\
\hline L533P & $\mathrm{CTG} / \mathrm{CCG}$ & 1 & \\
\hline L533R & $\mathrm{CTG} / \mathrm{CGG}$ & 4 & \\
\hline $\mathrm{Q} 510 \mathrm{H}+\mathrm{H} 526 \mathrm{Y}$ & $\mathrm{CAG} / \mathrm{CAC}+\mathrm{CAC} / \mathrm{TAC}$ & 1 & \\
\hline L511P + D516G & $\mathrm{CTG} / \mathrm{CCG}+\mathrm{GAC} / \mathrm{GGC}$ & 1 & \\
\hline$\angle 511 P+Q 513 P$ & $\mathrm{CTG} / \mathrm{CCG}+\mathrm{CAA} / \mathrm{CCA}$ & 1 & \\
\hline $\begin{array}{l}\text { L511P + D516G + } \\
\text { N518S }\end{array}$ & $\begin{array}{l}\mathrm{CTG} / \mathrm{CCG}+\mathrm{GAC} / \mathrm{GGC}+ \\
\mathrm{AAC} / \mathrm{GAC}\end{array}$ & 1 & \\
\hline $\mathrm{N} 518 \mathrm{~S}+\mathrm{H} 526 \mathrm{P}$ & $\mathrm{AAC} / \mathrm{AGC}+\mathrm{CAC} / \mathrm{CCC}$ & 1 & \\
\hline S512T + D516G & $A G C / A C G+G A C / G G C$ & 1 & \\
\hline$D 516 A+L 533 P$ & $\mathrm{GAC} / \mathrm{GCC}+\mathrm{CTG} / \mathrm{CCG}$ & 1 & \\
\hline$H 526 N+L 533 P$ & $\mathrm{CAC} / \mathrm{AAC}+\mathrm{CTG} / \mathrm{CCG}$ & 1 & \\
\hline$H 526 Q+L 533 P$ & $\mathrm{CAC} / \mathrm{CAG}+\mathrm{CTG} / \mathrm{CCG}$ & 1 & \\
\hline $\begin{array}{l}\text { H526Y + S531T+ } \\
\text { L530R }\end{array}$ & $\begin{array}{l}\mathrm{CAC/TAC}+\mathrm{TCG} / \mathrm{ACG}+ \\
\mathrm{CTG} / \mathrm{CGT}\end{array}$ & 1 & \\
\hline$L 511 P+S 531 L$ & $\mathrm{CTG} / \mathrm{CCG}+\mathrm{TCG} / \mathrm{TTG}$ & 1 & \\
\hline$D 516 A+S 531 L$ & $\mathrm{GAC} / \mathrm{GCC}+\mathrm{TCG} / \mathrm{TTG}$ & 1 & \\
\hline $\mathrm{D} 516 \mathrm{~V}+\mathrm{S} 531 \mathrm{~L}$ & $\mathrm{GAC} / \mathrm{GTC}+\mathrm{TCG} / \mathrm{TTG}$ & 1 & \\
\hline$S 531 L+L 533 R$ & $\mathrm{TCG} / \mathrm{TTG}+\mathrm{CTG} / \mathrm{CGG}$ & 1 & \\
\hline$H 526 D+L 533 R$ & $\mathrm{CAC} / \mathrm{GAC}+\mathrm{CTG} / \mathrm{CGG}$ & 1 & \\
\hline$H 526 \mathrm{Y}+\mathrm{L} 533 \mathrm{R}$ & $\mathrm{CAC} / T \mathrm{AC}+\mathrm{CTG} / \mathrm{CGG}$ & 1 & \\
\hline$S 531 L+L 533 S$ & $\mathrm{TCG} / \mathrm{TT}+\mathrm{CTG} / \mathrm{TCG}$ & 2 & \\
\hline WT & & 12 & 45 \\
\hline Fail & & 3 & \\
\hline
\end{tabular}

R: resistance; S: susceptibility; WT: wild type. sputum samples (41.7\%). The INH and AMK showed the highest specificity (100\%) in all the detecting drugs and samples. These results were present in Table 5.

\section{Discussion}

In this study, we developed a method for detecting RIF, INH, EMB, SM, OFL and AMK resistance by the pyrosequencing technology and evaluated this method on a panel of 229 clinical samples of M.tuberculosis. We optimized the pyrosequencing conditions to detect drug resistance to six anti-TB drugs. In the pyrosequencing operating system,two modes, SQA and SNP, could be used, but the two modes differed in several aspects. For example, SQA mode detected a short and medium length DNA fragment, and SNP mode detected only a single base variation. In our experiments, although SQA mode could detect all 6 drugs resistance, we chose the SNP mode rather than SQA mode to detect the mutation of $k a t G, r p s l, e m b B$ and rrs based on the below reasons. The mutations of these genes were mainly involved a few point mutations. In detection resistance of $\mathrm{INH}$, only katG gene at codon 315 was detected; in EMB, only $e m b B$ gene at codon 306 was detected; in SM, only rpsl gene at codon 44 and 88 was detected; in AMK, only rrs gene at nucleotide position 1401 was detected. However, for $r p o B$ and $g y r A$ gene, we chose the SQA mode to detect the mutation because the sequence of interesting had been highly polymorphic and a short region should be sequenced. The most important advantage for choosing the SNP mode rather than SQA mode was that the former was quicker than the latter. By SNP mode, it was possible to sequence 96 samples in approximately $15 \mathrm{~min}$, while it needed $70 \mathrm{~min}$ by the SQA mode. Thus, the time needed by SNP mode was shorter approximately only one- fourth of the time needed by SQA mode. Another advantage with SNP mode over SQA mode was that it could greatly reduce the detection cost to be $1 / 3$.

The traditional gold standard for detection drug resistance of tuberculosis was the bacteriological methods. Therefore, we compared the results of pyrosequencing with the Bactec MGIT 960 mycobacterial detection system. The pyrosequencing approach showed different sensitivity and specificity among six drugs. For clinical isolates, the sensitivity of pyrosequencing for detecting resistance to the six drugs ranged from $58.7 \%$ to $94.4 \%$, and the specificity was above $87.7 \%$.

In RIF assay, compared to Bactec MGIT 960 DST, the sensitivity and specificity of the pyrosequencing method were similar to previously reported values [29]. The $95.0 \%$ $(192 / 202)$ of pyrosequencing results were concordant with the results of Bactec MGIT 960. Among the ten inconsistent specimens, one isolate which was RIF susceptible was resistant by prosequecing and the mutation was detected 
Table 4 Mutations of the katG, embB, rrs, gyrA and rpsl genes identified by pyrosequencing in clinical isolates and sputum samples

\begin{tabular}{|c|c|c|c|c|c|c|}
\hline \multirow[t]{2}{*}{ Drugs } & \multirow[t]{2}{*}{ Genes } & \multirow[t]{2}{*}{$\begin{array}{l}\text { Amino acid } \\
\text { change(s) }\end{array}$} & \multirow[t]{2}{*}{$\begin{array}{l}\text { Codon } \\
\text { change(s) }\end{array}$} & \multirow[t]{2}{*}{$\begin{array}{l}\text { Nucleotide } \\
\text { change }\end{array}$} & \multicolumn{2}{|c|}{$\begin{array}{l}\text { BACTEC } \\
960 \text { tests }\end{array}$} \\
\hline & & & & & $\mathbf{R}$ & $S$ \\
\hline \multirow[t]{6}{*}{$\mathrm{INH}$} & katG & & & & & \\
\hline & & S315T & AGC/ACC & & 133 & \\
\hline & & S315N & AGC/AAC & & 5 & \\
\hline & & S315T & AGC/ACA & & 3 & \\
\hline & & WT & & & 46 & 39 \\
\hline & & Fail & & & 3 & \\
\hline \multirow[t]{5}{*}{ SM } & rpsl & & & & & \\
\hline & & $\mathrm{K} 43 \mathrm{R}$ & $\mathrm{AAG} / \mathrm{AGG}$ & & 100 & 2 \\
\hline & & K88R & AAG/AGG & & 18 & 1 \\
\hline & & WT & & & 32 & 71 \\
\hline & & Fail & & & 3 & 2 \\
\hline \multirow[t]{7}{*}{ EMB } & $e m b B$ & & & & & \\
\hline & & M306l & ATG/ATA & & 17 & 4 \\
\hline & & M306I & ATG/ATC & & 2 & 2 \\
\hline & & M306l & ATG/CTG & & 7 & 2 \\
\hline & & M306V & ATG/GTG & & 50 & 4 \\
\hline & & WT & & & 57 & 80 \\
\hline & & Fail & & & 4 & \\
\hline \multirow[t]{15}{*}{ OFL } & gyrA & & & & & \\
\hline & & G88A & GGC/GCC & & 1 & \\
\hline & & G88C & GGC/TGC & & 2 & \\
\hline & & A90V & GCG/GTG & & 22 & \\
\hline & & S91P & TCG/CCG & & 8 & 1 \\
\hline & & D94N & GAC/AAC & & 5 & \\
\hline & & $\mathrm{D} 94 \mathrm{H}$ & GAC/CAC & & 3 & \\
\hline & & D94A & GAC/GCC & & 18 & \\
\hline & & D94G & GAC/GGC & & 54 & \\
\hline & & D94Y & GAC/TAC & & 5 & \\
\hline & & $\begin{array}{l}\text { A90V + } \\
\text { D94N }\end{array}$ & $\begin{array}{l}\text { GCG/GTG + } \\
\text { GAC/AAC }\end{array}$ & & 1 & \\
\hline & & $\begin{array}{l}\text { A90V + } \\
\text { D94G }\end{array}$ & $\begin{array}{l}\text { GCG/GTG + } \\
\text { GAC/GGC }\end{array}$ & & 1 & \\
\hline & & $\begin{array}{l}\text { A90V + } \\
\text { D94Y }\end{array}$ & $\begin{array}{l}\text { GCG/GTG + } \\
\text { GAC/TAC }\end{array}$ & & 1 & \\
\hline & & WT & & & 19 & 86 \\
\hline & & Fail & & & 2 & \\
\hline
\end{tabular}

AMK rrs

$\begin{array}{lll}\text { A1401G } & 34 & \\ \text { WT } & 10 & 178\end{array}$

at codon Leu 511 Pro. This mutation usually occurred in RIF resistant isolates together with other mutations [29]; therefore this mutation alone maybe had low predictive value for RIF resistance. The other nine phenotypical RIF resistant isolates did not detect a mutation in the RRDR and it was possible that another mutations existed outside the RRDR or elsewhere in the genome.

In INH assay, the specificity was high to be $100 \%$, whereas the sensitivity of detecting resistance to INH was much low. The relatively low sensitivity in the detection of INH resistance might be related to only katG 315 detected. Both inhA and $a p h C$ had also been demonstrated to confer the INH resistance [14,30]. So these genes might increase the sensitivity when evaluated.

In SM assay, the codon 43 and 88 of rpsl gene were detected by pyrosequencing and showed low sensitivity. In previous report, the mutations in position 513 or 516 of $r$ rs gene were correctly identified in SM-resistant clinical isolates [31]. Therefore, the sensitivity might increase when these genes involved.

The sensitivity and specificity of detection of EMB resistance were the lowest among six drugs, which were consistent with the previous study [32]. These results also suggested that codon 306 point mutation in the $e m b B$ gene was a poor indicator of EMB resistance, and other genes, such as $e m b C$ and $e m b A$ might confer EMB resistance [33].

The high specificity of the OFL assay (98.7\%) and the low sensitivity (86.4\%) were analyzed here. One OFLsusceptible isolates was identified as resistant by the pyrosequencing assay because the MIC $(0.5 \mu \mathrm{g} / \mathrm{ml})$ for this isolate was close to the critical concentration for OFL $(1.0 \mu \mathrm{g} / \mathrm{ml})$. The other 17 of the 125 phenotypical OFLresistant isolates did not detect a mutation in the QRDR of the gyrA gene, which might have other mutation existed other site in $g y r A$ or in $\operatorname{gyr} B$ gene [34].

The specificity of AMK resistance was $100 \%$, and the sensitivity was low (82.1\%). The 7 of the 39 AMK-resistant isolates without a mutation at position 1401 in the rrs gene suggested that another mutation might exist in other site of $r$ rs gene or other genes conferring AMK resistance. These results might provide the cues to further studies on AMK resistance.

In addition, we detected the resistance of 24 smearpositive sputum samples by pyrosequencing in re-treatment PTB patients, which showed that pyrosequencing approach could applied to detect smear-positive sputum specimens. Then the bacterial culture avoided by this direct examination of sputum samples, and the detecting turn-around time could greatly shorten. However, most of the samples in our study were quantified as $3+$ to $4+$ for acid-fast (AFB) staining, so this application could be used to study in large scale and in sputum specimen of $1+$ or $2+$ acid-fast (AFB) staining. The nested 
Table 5 Comparison of pyrosequencing and Bactec MGIT 960 DST

\begin{tabular}{|c|c|c|c|c|c|c|c|}
\hline \multirow{2}{*}{$\begin{array}{l}\text { Drugs and specimen } \\
\text { Clinical isolates }\end{array}$} & \multirow[t]{2}{*}{ Pyro. methods } & \multicolumn{2}{|c|}{ No. of samples by Bactec 960 method } & \multicolumn{3}{|c|}{ Mean\% $(95 \% \mathrm{Cl})$} & \multirow[b]{2}{*}{ Kappa } \\
\hline & & $\mathbf{R}$ & $S$ & Sensitivity & Specificity & Accuracy & \\
\hline \multirow[t]{2}{*}{$\mathrm{RIF}$} & $\mathrm{R}$ & 152 & 1 & 94.4 & 97.6 & 95.0 & 0.86 \\
\hline & $S$ & 9 & 40 & $89.7-97.0$ & 87.4-99.6 & & \\
\hline \multirow[t]{2}{*}{ INH } & $\mathrm{R}$ & 128 & 0 & 75.3 & 100 & 79.2 & 0.49 \\
\hline & $\mathrm{S}$ & 42 & 32 & $68.3-81.2$ & $89.3-100.0$ & & \\
\hline \multirow[t]{2}{*}{ SM } & $\mathrm{R}$ & 107 & 3 & 79.3 & 95.4 & 84.5 & 0.68 \\
\hline & $\mathrm{S}$ & 28 & 62 & $71.7-85.2$ & $87.3-98.4$ & & \\
\hline \multirow[t]{2}{*}{ EMB } & $\mathrm{R}$ & 71 & 10 & 58.7 & 87.7 & 70.3 & 0.43 \\
\hline & $\mathrm{S}$ & 50 & 71 & $49.8-67.1$ & 78.7-93.2 & & \\
\hline \multirow[t]{2}{*}{ OFL } & $\mathrm{R}$ & 108 & 1 & 86.4 & 98.7 & 91.1 & 0.82 \\
\hline & $\mathrm{S}$ & 17 & 77 & $79.3-91.3$ & $93.1-99.8$ & & \\
\hline \multirow[t]{2}{*}{ AMK } & $\mathrm{R}$ & 32 & 0 & 82.1 & 100 & 96.5 & 0.88 \\
\hline & $S$ & 7 & 159 & $67.3-91.0$ & $97.6-100.0$ & & \\
\hline \multicolumn{8}{|l|}{ Sputum samples } \\
\hline \multirow[t]{2}{*}{ RIF } & $\mathrm{R}$ & 15 & 1 & 83.3 & 83.3 & 83.3 & 0.6 \\
\hline & S & 3 & 5 & $60.8-94.2$ & $43.7-97.0$ & & \\
\hline \multirow[t]{2}{*}{ INH } & $\mathrm{R}$ & 13 & 0 & 76.5 & 100 & 83.3 & 0.66 \\
\hline & $S$ & 4 & 7 & $52.7-90.4$ & $64.6-100.0$ & & \\
\hline \multirow[t]{2}{*}{ SM } & $\mathrm{R}$ & 11 & 0 & 73.3 & 100 & 83.3 & 0.67 \\
\hline & $\mathrm{S}$ & 4 & 9 & $48.1-89.1$ & $70.0-100.0$ & & \\
\hline \multirow[t]{2}{*}{ EMB } & $\mathrm{R}$ & 5 & 2 & 41.7 & 81.8 & 60.9 & 0.23 \\
\hline & $\mathrm{S}$ & 7 & 9 & 19.3-68.1 & $52.3-94.9$ & & \\
\hline \multirow[t]{2}{*}{ OFL } & $\mathrm{R}$ & 13 & 0 & 86.7 & 100 & 91.7 & 0.83 \\
\hline & $\mathrm{S}$ & 2 & 9 & $62.1-96.3$ & 70.1-100.0 & & \\
\hline \multirow[t]{2}{*}{ AMK } & $\mathrm{R}$ & 2 & 0 & 40 & 100 & 87.5 & 0.51 \\
\hline & $\mathrm{S}$ & 3 & 19 & $11.8-76.9$ & $83.2-100.0$ & & \\
\hline
\end{tabular}

Cl: confidence interval.

PCR might be essential when detected the sputum specimens with $1+$ or $2+$.

\section{Conclusions}

We concluded that the pyrosequencing is a rapid and high-throughput method for the detection of resistance to RIF, INH, SM, EMB, OFL and AMK in M.tuberculosis. Pyrosequencing can be used as a practical molecular diagnostic tool for screening and predicting the resistance for re-treatment pulmonary tuberculosis patients.

\section{Additional file}

Additional file 1: The detailed information of sequences in this study.

\section{Competing interests}

The authors declare that they have no competing interests.
Authors' contributions

RJZ, CTZ, ZYH and BXG designed the study. RJZ, QG, LHQ, JML, CTZ, HYC and ZHL performed the experiments. CTZ, RJZ and JML performed the statistical analysis. CTZ and RJZ wrote the manuscript. All authors contributed to the study and had read and approved the final manuscript. $B X G$ is the guarantor.

\section{Acknowledgements}

This work was supported by National Natural Science Foundation of China (No. 81101217, 81071799) and by the Grants from Science and Technology Commission of Shanghai Municipality (No. 10411955100) and Health Bureau of Jiangsu Province Preventive Medicine Project (No. Y2012095).

Received: 14 March 2013 Accepted: 9 April 2014 Published: 13 April 2014

\section{References}

1. Prammananan T, Chaiprasert A, Leechawengwongs M: In vitro activity of linezolid against multidrug-resistant tuberculosis (MDR-TB) and extensively drug-resistant (XDR)-TB isolates. Int J Antimicrob Agents 2009, 33(2):190-191.

2. Pieroni M, Tipparaju SK, Lun S, Song Y, Sturm AW, Bishai WR, Kozikowski AP: Pyrido[1,2-a]benzimidazole-based agents active against tuberculosis (TB), multidrug-resistant (MDR) TB and extensively drug-resistant (XDR) TB. ChemMedChem 2011, 6:334-342. 
3. Denholm J: The most recent report from the World Health Organization found that, worldwide, approximately $5 \%$ of new tuberculosis cases are caused by multidrug-resistant strains (MDR TB). J Travel Med 2010, 17(3):216.

4. World Health Organization: Towards universal access to diagnosis and treatment of multidrug-resistant and extensively drug-resistant tuberculosis by 2015, WHO progress report. Geneva: 2011.

5. World Health Organization: Tuberculosis profile- Bangladesh (high TB burden; high MDR-TB burden). WHO progress report 2010. World Health Organization;

6. Noeske J, Voelz N, Fon E, Abena Foe JL: Early results of systematic drug susceptibility testing in pulmonary tuberculosis retreatment cases in Cameroon. BMC Res Notes 2012, 5:160.

7. Zhang Y, Yew WW: Mechanisms of drug resistance in Mycobacterium tuberculosis. Int J Tuberc Lung Dis 2009, 13:1320-1330.

8. Ramaswamy S: Musser JM:Molecular genetic basis of antimicrobial agent resistance in Mycobacterium tuberculosis: 1998 update. Tuber Lung Dis 1998, 79:3-29.

9. Viveiros M, Leandro C, Rodrigues L, Almeida J, Bettencourt R, Couto I, Carrilho L, Diogo J, Fonseca A, Lito L, Lopes J, Pacheco T, Pessanha M, Quirim J, Sancho L, Salfinger M, Amaral L: Direct application of the INNO-LiPA Rif.TB line-probe assay for rapid identification of Mycobacterium tuberculosis complex strains and detection of rifampin resistance in 360 smear-positive respiratory specimens from an area of high incidence of multidrug-resistant tuberculosis. J Clin Microbiol 2005, 43:4880-4884.

10. Rossau R, Traore H, De Beenhouwer H, Mijs W, Jannes G, De Rijk P, Portaels F: Evaluation of the INNO-LiPA Rif. TB assay, a reverse hybridization assay for the simultaneous detection of Mycobacterium tuberculosis complex and its resistance to rifampin. Antimicrob Agents Chemother 1997, 41:2093-2098.

11. Sandgren A, Strong M, Muthukrishnan P, Weiner BK, Church GM, Murray MB: Tuberculosis drug resistance mutation database. PLoS Med 2009, 6:e2.

12. Ramasubban G, Therese KL, Vetrivel U, Sivashanmugam M, Rajan P, Sridhar R, Madhavan HN, Meenakshi N: Detection of novel coupled mutations in the katG gene (His276Met, Gln295His and Ser315Thr) in a multidrug-resistant Mycobacterium tuberculosis strain from Chennai, India, and insight into the molecular mechanism of isoniazid resistance using structural bioinformatics approaches. Int J Antimicrob Agents 2011, 37:368-372.

13. Ando H, Kitao T, Miyoshi-Akiyama T, Kato S, Mori T, Kirikae T: Downregulation of katG expression is associated with isoniazid resistance in Mycobacterium tuberculosis. Mol Microbiol 2011, 79:1615-1628.

14. Engstrom A, Perskvist N, Werngren J, Hoffner SE, Jureen P: Comparison of clinical isolates and in vitro selected mutants reveals that tlyA is not a sensitive genetic marker for capreomycin resistance in Mycobacterium tuberculosis. J Antimicrob Chemother 2011, 66:1247-1254.

15. Piton J, Petrella S, Delarue M, Andre-Leroux G, Jarlier V, Aubry A, Claudine Mayer-mail C: Structural insights into the quinolone resistance mechanism of Mycobacterium tuberculosis DNA gyrase. PLoS One 2010, 5:e12245.

16. Wang $F$, Shen $H$, Guan $M$, Wang $Y$, Feng $Y$, Weng $X$, Wang $H$, Zhang W: High-resolution melting facilitates mutation screening of $r p s L$ gene associated with streptomycin resistance in Mycobacterium tuberculosis. Microbiol Res 2011, 166:121-128.

17. Park KS, Kim JY, Lee JW, Hwang YY, Jeon K, Koh WJ, Ki CS, Lee NY: Comparison of the Xpert MTB/RIF and Cobas TaqMan MTB assays for detection of Mycobacterium tuberculosis in respiratory specimens. J Clin Microbiol 2013, 51(10):3225-3227.

18. Lyu J, Kim MN, Song JW, Choi CM, Oh YM, Lee SD, Kim WS, Kim DS, Shim TS: GenoType ${ }^{\circledast}$ MTBDRplus assay detection of drug-resistant tuberculosis in routine practice in Korea. Int J Tuberc Lung Dis 2013, 17(1):120-124.

19. Ronaghi $M$, Uhlen $M$, Nyren $P$ : A sequencing method based on real-time pyrophosphate. Science 1998, 281:363-365.

20. Nyren P: The history of pyrosequencing. Methods Mol Biol 2007, 373:1-14

21. Ronaghi M, Karamohamed S, Pettersson B, Uhlen M, Nyren P: Real-time DNA sequencing using detection of pyrophosphate release. Anal Biochem 1996, 242:84-89.

22. Jureen P, Engstrand L, Eriksson S, Alderborn A, Krabbe M, Hoffner SE: Rapid detection of rifampin resistance in Mycobacterium tuberculosis by Pyrosequencing technology. J Clin Microbiol 2006, 44:1925-1929.

23. Garza-Gonzalez E, Gonzalez GM, Renteria A, Cruz-Pulido W, Rivera G, Bocanegra-Garcia $V$ : A pyrosequencing method for molecular monitoring of regions in the inhA, ahpC and rpoB genes of Mycobacterium tuberculosis. Clin Microbiol Infect 2010, 16:607-612
24. Garcia-Sierra N, Lacoma A, Prat C, Haba L, Maldonado J, Ruiz-Manzano J, Gavin P, Samper S, Ausina V, Dominguez J: Pyrosequencing for rapid molecular detection of rifampin and isoniazid resistance in Mycobacterium tuberculosis strains and clinical specimens. J Clin Microbio/ 2011, 49:3683-3686.

25. Kahla IB, Henry M, Boukadida J, Drancourt M: Pyrosequencing assay for rapid identification of Mycobacterium tuberculosis complex species. BMC Res Notes 2011, 4:42.

26. Huq F, Moyen Uddin M: Isolation and identification of mycobacteria from patients with pulmonary tuberculosis. Bangladesh Med Res Counc Bull 1984, 10:39-44.

27. Camus JC, Pryor MJ, Medigue C, Cole ST: Re-annotation of the genome sequence of Mycobacterium tuberculosis H37Rv. Microbiology 2001, 148:2967-2973.

28. Garrigó M, Aragón LM, Alcaide F, Borrell S, Cardeñosa E, Galán JJ, Gonzalez-Martín J, Martin-Casabona N, Moreno C, Salvado M, Coll P: Multicenter laboratory evaluation of the MB/BacT Mycobacterium detection system and the BACTEC MGIT 960 system in comparison with the BACTEC 460 TB system for susceptibility testing of Mycobacterium tuberculosis. J Clin Microbiol 2007, 45(6):1766-1770.

29. Engstrom A, Morcillo N, Imperiale B, Hoffner SE, Jureen P: Detection of first- and second-line drug resistance in Mycobacterium tuberculosis clinical isolates by pyrosequencing. J Clin Microbiol 2012, 50:2026-2033.

30. Kiepiela P, Bishop KS, Smith AN, Roux L, York DF: Genomic mutations in the katG, inhA and aphC genes are useful for the prediction of isoniazid resistance in Mycobacterium tuberculosis isolates from Kwazulu Natal, South Africa. Tuber Lung Dis 2000, 80:47-56.

31. Cuevas-Córdoba B, Cuellar-Sánchez A, Pasissi-Crivelli A, Santana-Álvarez CA, Hernández-Illezcas J: Zenteno-Cuevas R:rrs and rpsL mutations in streptomycin-resistant isolates of Mycobacterium tuberculosis from Mexico. J Microbiol Immunol Infect 2013, 46(1):30-34.

32. Seagar AL, Neish B, Laurenson IF: Comparison of two in-house real-time PCR assays with MTB Q-PCR Alert and GenoType MTBDRplus for the rapid detection of mycobacteria in clinical specimens. J Med Microbiol 2012, 61:1459-1464.

33. Sreevatsan $\mathrm{S}$, Stockbauer KE, Pan X, Kreiswirth BN, Moghazeh SL, Jacobs WR $\mathrm{Jr}$, Telenti A, Musser JM: Ethambutol resistance in Mycobacterium tuberculosis: critical role of embB mutations. Antimicrob Agents Chemother 1997, 41:1677-1681.

34. Ilina EN, Shitikov EA, Ikryannikova LN, Alekseev DG, Kamashev DE, Malakhova MV, Parfenova TV, Afanas'ev MV, Ischenko DS, Bazaleev NA, Smirnova TG, Larionova EE, Chernousova LN, Beletsky AV, Mardanov AV, Ravin NV, Skryabin KG, Vadim MG: Comparative Genomic Analysis of Mycobacterium tuberculosis Drug Resistant Strains from Russia. PLOS One 2013, 8(2):e56577.

doi:10.1186/1471-2334-14-200

Cite this article as: Zheng et al:: Pyrosequencing for rapid detection of Tuberculosis resistance in clinical isolates and Sputum samples from re-treatment Pulmonary Tuberculosis patients. BMC Infectious Diseases $201414: 200$

\section{Submit your next manuscript to BioMed Central and take full advantage of:}

- Convenient online submission

- Thorough peer review

- No space constraints or color figure charges

- Immediate publication on acceptance

- Inclusion in PubMed, CAS, Scopus and Google Scholar

- Research which is freely available for redistribution 